\title{
LPS levels in root canals after the use of ozone gas and high frequency electrical pulses
}

Tiago André Fontoura de MELO(a) Grasiela Sabrina Longhi GRÜNDLING(a)

Francisco MONTAGNER ${ }^{(b)}$

Alcione Luiz SCUR ${ }^{(c)}$

Liviu STEIER $R^{(d)}$

Roberta Kochenborger SCARPARO(a) José Antônio Poli de FIGUEIREDO(a) Fabiana Vieira VIER-PELISSER ${ }^{(a)}$

(a)Pontifícia Universidade Católica do Rio Grande do Sul - PUCRS, School of Dentistry, Clinical Department, Porto Alegre, RS, Brazil.

(b)Pontifícia Universidade Católica do Rio Grande do Sul - PUCRS, School of Dentistry, Endodontics Division, Porto Alegre, RS, Brazil.

(c) Private Practice, Gramado, RS, Brazil.

(d) University of Warwick, Warwick Medical School, Institute of Clinical Education, Coventry, United Kingdom.
Declaration of Interests: The authors certify that they have no commercial or associative interest that represents a conflict of interest in connection with the manuscript.

Corresponding Author:

Tiago André Fontoura de Melo

E-mail: tafmelo@gmail.com

DOI: 10.1590/1807-3107BOR-2016.vol30.0019

Submitted: Jun 27, 2015

Accepted for publication: Sep 15, 2015

Last revision: Nov 09, 2015
Abstract: The present study aims to verify the effect of ozone gas (OZY ${ }^{\circledast}$ System) and high frequency electric pulse (Endox ${ }^{\circledR}$ System) systems on human root canals previously contaminated with Escherichia coli lipopolysaccharide (LPS). Fifty single-rooted teeth had their dental crowns removed and root lengths standardized to $16 \mathrm{~mm}$. The root canals were prepared up to \#60 hand K-files and sterilized using gamma radiation with cobalt 60 . The specimens were divided into the following five groups $(n=10)$ based on the disinfection protocol used: OZY ${ }^{\circledR}$ System, one 120-second-pulse (OZY 1p); OZY ${ }^{\circledR}$ System, four 24-second-pulses (OZY 4p); and Endox ${ }^{\circledR}$ System (ENDOX). Contaminated and non-contaminated canals were exposed only to apyrogenic water and used as positive $(\mathrm{C}+$ ) and negative (C-) controls, respectively. LPS (O55:B55) was administered in all root canals except those belonging to group C-. After performing disinfection, LPS samples were collected from the canals using apyrogenic paper tips. Limulus Amoebocyte Lysate (LAL) was used to quantify the LPS levels, and the data obtained was analyzed using one-way ANOVA. The disinfection protocols used were unable to reduce the LPS levels significantly $(p=0.019)$. The use of ozone gas and high frequency electric pulses was not effective in eliminating LPS from the root canals.

Keywords: Endodontics; Endotoxins; Microbiology; Root Canal Therapy.

\section{Introduction}

Microorganisms and their byproducts, such as bacterial LPS (endotoxin), play a key role in the development of apical periodontitis. ${ }^{1,2,3}$ LPS is released during multiplication or death of gram-negative bacteria, and is associated with many biological effects, such as release of pro-inflammatory mediators ${ }^{4}$ and induction of periapical bone resorption. ${ }^{5}$ The endotoxins can adhere to mineralized tissues ${ }^{6}$ and disseminate through the dentinal tubules, ${ }^{7}$ making root canal sterilization difficult if only chemo-mechanical preparation is used. ${ }^{8}$ Although the effects of different disinfection strategies ${ }^{9,10,11,12}$ on LPS have already been examined, none of them are fully effective as yet.

Electrofulguration and ozone gas equipment were tested for microorganisms, with satisfactory results. ${ }^{13,14,15,16}$ Electrofulguration system such as Endox $^{\circledR}$, deliver electrical pulses into the root canal via a stainless steel surgical needle that works as an active electrode, ${ }^{15}$ thereby 
eliminating organic and inorganic content through steaming. ${ }^{17}$ Ozone is a very reactive gas that has the ability to oxidize cell walls and the cytoplasmic membrane of microorganisms. ${ }^{14}$

Till date, there have been no studies investigating the effects of this equipment on LPS. Thus, the objective of the present study was to assess in vitro the effect of ozone gas and high frequency electrical pulses on LPS levels in infected root canals.

\section{Methodology}

The present study was approved by the Ethics and Research Committee of Pontifícia Universidade Católica do Rio Grande do Sul - PUCRS (Protocols no. 5859 and 811.207).

All plates and materials used in this study were sterilized using cobalt 60 gamma radiation $(20 \mathrm{kGy}$ for 6 hours) (Empresa Brasileira de Radiações - EMBRARAD, Cotia, Brazil), as previously described. ${ }^{2}$

\section{Sample selection and preparation}

Fifty single-root premolars had their dental crowns sectioned in such a way that the root length was standardized to $16 \mathrm{~mm}$. A $15 \mathrm{~mm}$ working length (WL) was established. The canals were manually prepared using the serial technique up to \#60 hand K-files (Dentsply/Maillefer Instruments S.A., Ballaigues, Switzerland), and irrigated using 2\% sodium hypochlorite (Iodontosul, Porto Alegre, Brazil).

The smear layer was removed using $17 \%$ trisodium EDTA (Iodontosul, Porto Alegre, Brazil) for 5 minutes after agitation in the root canal with a \#60 hand K-file for one minute. Final irrigation was performed using $2 \mathrm{~mL}$ of $2 \%$ sodium hypochlorite, and the root canals were dried using sterilized paper points (Dentsply/Maillefer Instruments S.A., Ballaigues, Switzerland).
The teeth were randomly fixed in 12-wells culture plates (Kasvi, Curitiba, Brazil) with Durepoxi ${ }^{\circledR}$ (Henkel, Düsseldorf, Germany). Each plate contained two teeth from each of the five experimental groups (Table).

\section{Specimen contamination}

This protocol was performed according to Signoretti et al. ${ }^{18}$ The teeth were inoculated with $30 \mu \mathrm{L}$ of a solution containing the endotoxin Escherichia coli O55:B5 (Lonza, Walkersville, USA) inside a laminar flow chamber with the help of a micro pipette.

A solution containing LPS $(80 \mathrm{EU} / \mathrm{mL})$, previously diluted in apyrogenic water $(50.37 \mathrm{EU} / \mathrm{mL})$, was used to contaminate of all specimens except those belonging to group $\mathrm{C}$ - that were inoculated with $30 \mu \mathrm{L}$ of apyrogenic water.

Apyrogenic cotton pellets were placed in the cervical portion of the canals in all samples. The plates containing the samples were sealed and incubated for 24 hours at $37^{\circ} \mathrm{C}$ temperature.

\section{Desinfection Procedure}

Prior to performing the clinical protocols, all root canals were filled with $10 \mu \mathrm{L}$ of apyrogenic water. The disinfection protocols used in each experimental group were as follows:

a. Group C+: the LPS contaminated canals did not undergo any disinfection protocol.

b. Group C-: the canals had no previous LPS inoculation and did not undergo any disinfection protocol.

c. Group OZY 1p: the tip of the OZY ${ }^{\circledast}$ system was introduced up to the working length of the root canal and one 120-second-long pulse was delivered, as described by Kustarsi et al. ${ }^{16}$

Table. Descriptive chart for the experimental groups and disinfection protocols used.

\begin{tabular}{lccc}
\hline Experimental Group & $\mathrm{n}$ & Contamination/LPS & Clínic Protocol \\
\hline $\mathrm{C}+$ & 10 & Yes & Without treatment \\
C- & 10 & No & Without treatment \\
OZY 1p & 10 & Yes & OZY ${ }^{\circledR}$ System (1 pulse $\left.-120 \mathrm{~s}\right)$ \\
OZY $4 \mathrm{p}$ & 10 & Yes & OZY® System (4 pulses $-24 \mathrm{~s}$ each) \\
ENDOX & 10 & Yes & Endox $^{\circledR}$ System \\
\hline
\end{tabular}


d. Group OZY 4p: the $\mathrm{OZY}^{\circledR}$ system was introduced up to the working length of the root canals and four 24-second pulses were delivered, according to Case et al. ${ }^{14}$ There was a 5 second interval between pulses.

An adapter was developed for the already available "Oto" tip to compensate for the unavailability of a specific tip for use with the OZY ${ }^{\circledR}$ system (Endox SRL, Italy). It was made of 420 surgical steel and had $0.20 \mathrm{~mm}$ diameter at the end and $30 \mathrm{~mm}$ length (Figure 1).

The OZY ${ }^{\circledR}$ system was operated at $5 \mathrm{~N}$ intensity in accordance with the manufacturer's instructions. The only variation between the OZY 1p and OZY 4p groups was in the device activation time.

a. Group ENDOX: the protocol used for the Endox ${ }^{\circledR}$ system (Lysis srl, Milan, Italy) was the same as that described by Lendini et al. ${ }^{17}$ The black probe of the device (measuring $30 \mathrm{~mm}$ in length and $0.20 \mathrm{~mm}$ in diameter) was introduced into the root canal. Two pulses were administered in the medium third of the root canal ( $5 \mathrm{~mm}$ short of WL), and two additional pulses in the apical third (in WL). Thus, four $600 \mathrm{kHz}$ pulses were delivered, with standard time for each application being $1 / 10$ of a second.

\section{Determination of LPS Levels}

The canals content were collected by holding three apyrogenic \#60 paper points (Tanari ${ }^{\circledR}$, Manaus,

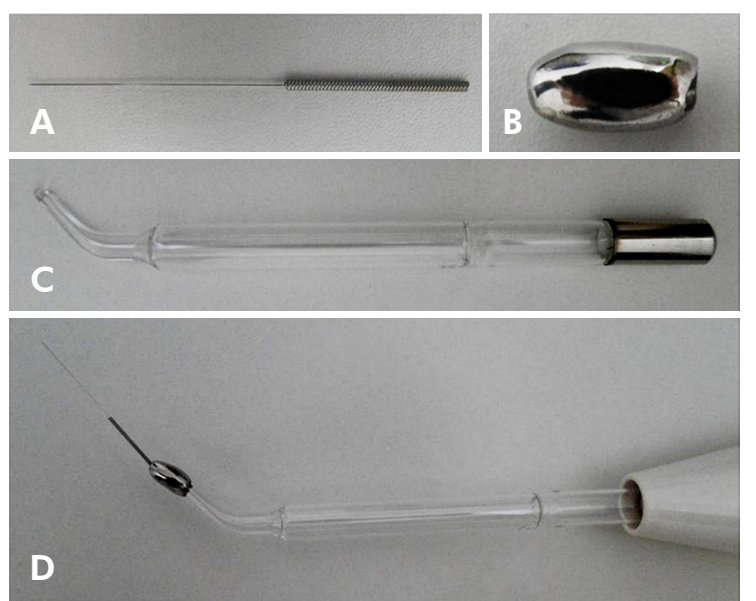

Figure 1. Adapter at the "Oto" tip of the $\mathrm{OZY}^{\oplus}$ system: (A) "endodontic" tip, (B) adapter, (C) "Oto" tip and (D) mounted $O Z^{\circledR}$ system.
Brazil) in position for 10 seconds. They were then transferred into glass tubes, sealed, and stored at $-20^{\circ} \mathrm{C}$ until LPS levels quantification was perfomed.

Quantification of an apyrogenic water sample and the paper tips used was previously assessed in order to check the accuracy of LPS level estimation

The glass tubes containing the paper tips were filled with $1 \mathrm{~mL}$ apyrogenic water, warmed at $37^{\circ} \mathrm{C}$ for one hour, and finally centrifuged (Phoenix, Araraquara, Brazil) for 1 minute.

The chromogenic kinetic test of the turbidimetric LAL (Pyrogent 5000 ${ }^{\circledR}$, BioWhitaker, Cambrex Co., Walkersville, USA) was used to quantify the LPS levels in the root canals, as already described and applied in some studies. ${ }^{2,11}$

The samples collected from the canals were mixed with the LAL reagent and automatically monitored over time with the help of a photometer until turbidity developed. The increase in optical density was measured by the reaction time, which is inversely proportional to the amount of LPS present in the sample.

A curve was drawn using the endotoxins supplied by the kit, with known concentration as a parameter for estimating LPS levels present in the root canals All the samples collected for analysis and quantification were diluted ten times.

For test validation, the assays were performed twice in distinct wells in a 96-well microplate (Corning Costar, Cambridge, USA). One hundred $\mu \mathrm{L}$ of apyrogenic water was added to the negative control, $100 \mu \mathrm{L}$ for standard endotoxin at different concentrations for the curve, and $100 \mu \mathrm{L}$ from each sample for quantification. LPS level was measured according to the manufacturers' instructions.

The microplate was incubated in enzyme immunoassay reader (Ultramark, Bio-Rad Laboratories Inc., Hercules, USA) for 10 minutes at $37 \pm 1^{\circ} \mathrm{C}$, and the reader was coupled with a computer with Wink QCL software version 4 (BioWittaker, Cambrex Co. Walkersville, EUA).

After incubation, $100 \mu \mathrm{L}$ of LAL chromogenic kinetic reagent (Sigma Chemical Company St. Louis, USA) was added to each plate well to start quantification of LPS levels. 


\section{Statistical analysis}

$\mathrm{EU} / \mathrm{mL}$ measures were logarithmically transformed to reduce asymmetry and heteroscedasticity. The data were reported as geometric mean, maximum, and minimum values. The groups were compared using-way variance analysis (one-way ANOVA) on the logarithms, and the significance level was set at $5 \%(\mathrm{p} \leq 0.05)$.

\section{Results}

The standard curve for LAL assay validation followed the linearity criteria $(r=1)$. The LAL assay showed that LPS was present in 100\% of the root canals initially contaminated.

Results are shown in Figure 2. There were no significant differences $(p=0.019)$ in the reduction of endotoxin between the experimental groups undergoing disinfection and group C+. However, a significant difference was observed when the endotoxin concentration of the group C-specimens was compared with the other groups.

\section{Discussion}

Successful endodontic treatment of infected teeth involves elimination of microorganisms as well as inactivation of endotoxins and other toxic products. ${ }^{2}$ Thus, considering the results observed when using the ozone gas system ${ }^{14,19}$ and high frequency electrical pulses ${ }^{13,15}$ on microbial strains, analysis of these systems on bacterial LPS was also thought to be pertinent.

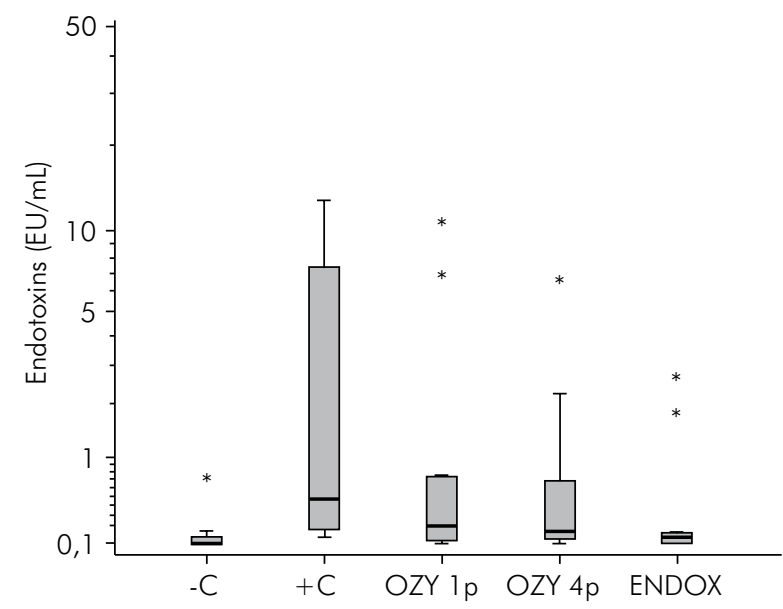

Figure 2. Boxplot distribution of endotoxin concentration in $\mathrm{EU} / \mathrm{mL}$ for each experimental group.
The endotoxin used in the present study was obtained from Escherichia coli as it is the standard endotoxin employed in most research studies. ${ }^{12,20}$ LAL assay was used to quantify LPS levels as it is extremely sensitive to measurement. ${ }^{2,10}$

The turbidimetric LAL assay indicated that the endotoxins were present in all previously contaminated samples. The concentrations ranged from 0.1 to $12.8 \mathrm{EU} / \mathrm{mL}$ in the positive control group, and this was in accordance with Jacinto et al. ${ }^{21}$ who reported endotoxin concentrations ranging between 2.3 and $22.1 \mathrm{EU} / \mathrm{mL}$. This range in values can be attributed to the sensitivity of the test that allows detection of slight variations, and to the differences in the dental anatomy of species. However, the LPS concentration obtained was inferior to the approximate value of $50.37 \mathrm{EU} / \mathrm{mL}$ injected into each root canal. This can be justified by the fact that the samples were collected from the main canal and not from the deeper dentinal tubular region. According to Horiba et al., the endotoxin is capable of penetrating into the dentinal tubules four times deeper than that of the microorganisms, reaching $800 \mu \mathrm{m}$ in depth, mainly due to its low molecular weight. Thus, there is a need for auxiliary strategies that complement mechanical instrumentation to perform effective root canal disinfection.

None of the clinical protocols performed herein promoted significant reduction of endotoxin levels in relation to the positive control group. This can be justified by the fact that the principle anti-microbial action ${ }^{14,15}$ of the two systems involves causing damage to the structure of the microbial coating. However, LPS does not present a coating structure and it is mainly composed of specific polysaccharide $\mathrm{O}$, a central nucleus, and a lipid component $\mathrm{A},{ }^{22}$ thereby yielding these systems ineffective against it. This was confirmed by Cardoso et al. ${ }^{23}$ who showed that ionized water was unable to neutralize the root canal endotoxins. The results suggest presence of endotoxins in the ozone water group as well the saline solution control group. Another factor that may corroborate the results obtained in this study is the ephemeral ozone gas half-life. ${ }^{24}$ The only techniques that have been tested so far and have showed a certain degree of effectiveness against LPS are (a) the use of calcium hydroxide as an intra-canal medication $^{12,25,26}$ as it hydrolyses lipid A and changes 
it into chains of fatty acid and nontoxic sugars, ${ }^{27}$ and

(b) the application of laser Nd:YAG. ${ }^{9}$

The results obtained in this study reinforce the importance of instrumentation in addition to any disinfection protocol, $11,28,29$ especially with regard to bacterial LPS that strongly adheres to the dentinal wall ${ }^{6}$ and makes it necessary to use endodontic instruments for its removal. Some studies have reported endotoxin decrease up to $44.4 \%,{ }^{30} 59.99 \%,{ }^{28}$ and $57.98 \%{ }^{10}$ after chemo-mechanical preparation.

Martinho et al. ${ }^{11}$ noticed $98.06 \%$ decrease in the endotoxin after performing canal preparation with $\mathrm{NiTi}\left(\mathrm{Mtwo}^{\circledR}\right)$ rotatory tools under irrigation with $2.5 \%$ sodium hypochlorite solution, and $96.27 \%$ decrease when the rotatory preparation was associated with irrigation using apyrogenic saline solution. According to the authors, a basic factor that must be taken into account when performing chemo-mechanical preparation to decrease bacterial LPS is the enlargement the apical third. Enlargements over size 30 instruments are recommended for removal of endotoxin as well as

\section{References}

1. KakehashiS, Stanley HR, Fitzgerald RJ. The effects of surgical exposures of dental pulps in germ-free and conventional laboratory rats. Oral Surg Oral Med Oral Pathol. 1965;20:340-9. doi:10.1016/0030-4220(65)90166-0

2. Marinho ACS, Martinho FC, Zaia AA, Ferraz CCR, Gomes BPFA. Monitoring the effectiveness of root canal procedures on endotoxin levels found in teeth with chronic apical periodontitis. J Appl Oral Sci. 2014;22(6):490-5. doi:10.1590/1678-775720130664

3. Khabbaz MG, Anastasiadis PL, Sykaras SN. Determination of endotoxins in the vital pulp of human carious teeth: association with pulpal pain. Oral Surg Oral Med Oral Pathol Oral Radiol Endod. 2001;91(5):587-93. doi:10.1067/moe.2001.113831

4. Agarwal S, Piesco NP, Johns LP, Riccelli AE. Differential expression of IL-1 beta, TNF-alpha, IL-6, and IL-8 in human monocytes in response to lipopolysaccharides from different microbes. J Dent Res. 1995;74(4):1057-65. doi:10.1177/00220345950740040501

5. Hong CY, Lin SK, Kok SH, Cheng SJ, Lee MS, Wang TM, et al. The role of lipopolysaccharide in infectious bone resorption of periapical lesion. J Oral Pathol Med. 2004;33(3):162-9. doi:10.1111/j.0904-2512.2004.00045.x

6. Barthel CR, Levin LG, Reisner HM, Trope M. TNF-alpha release in monocytes after exposure to calcium hydroxide infected dentin. Furthermore, this approach allows for deeper irrigation and increases the probability of opening secondary canals and apical deltas. However, this was contradicted by Martinho et al. ${ }^{29}$ who tested different systems with different designs, conicities, and tapers such as WaveOne ${ }^{\circledR}$, Reciproc ${ }^{\circledR}$, Protaper $^{\circledR}$, and Mtwo ${ }^{\circledR}$ and did not observe any statistically significant differences in the decrease of bacterial LPS. The percentage of LPS reduction observed with each system was $95.15 \%, 96.21 \%$, $97.98 \%$, and $96.34 \%$, respectively.

\section{Conclusion}

Based on the results of this study, the clinical protocols used for disinfection were unable to reduce LPS levels. The use of ozone gas and high frequency electric pulses was not effective in the elimination of LPS in root canals.

\section{Acknowledgments}

This study was supported by grants from Fundação de Amparoà Pesquisa do Estado do Rio Grande do Sul -FAPERGS (process no. 12/0439-0 / edital no. 13/2011).

treated Escherichia coli LPS. Int Endod J. 1997;30(3):155-9. doi:10.1046/j.1365-2591.1997.00066.x

7. Horiba N, Maekawa Y, Matsumoto T, Nakamura H. A study of the distribution of endotoxin in the dentinal wall of infected root canals. J Endod. 1990;16(7):331-4. doi:10.1016/S0099-2399(06)81944-8

8. Byström A, Sundqvist G. Bacteriologic evaluation of the efficacy of mechanical root canal instrumentation in endodontic therapy. Scand J Dent Res. 1981;89(4):321-8. doi:10.1111/j.1600-0722.1981.tb01689.x

9. Archilla JR, Moreira MS, Miyagi SP, Bombana AC, Gutknecht $\mathrm{N}$, Marques MM. Single session of Nd:YAG laser intracanal irradiation neutralizes endotoxin in dental root dentin. J Biomed Opt. 2012;17(11):118002. doi:10.1117/1.JBO.17.11.118002

10. Gomes BPFA, Martinho FC, Vianna ME. Comparison of $2.5 \%$ sodium hypochlorite and $2 \%$ chlorhexidine gel on oral bacterial lipopolysaccharide reduction from primarily infected root canals. J Endod. 2009;35(10):1350-3. doi:10.1016/j.joen.2009.06.011

11. Martinho FC, Chiesa WMM, Marinho ACS, Zaia AA, Ferraz CCR, Almeida JFA, et al. Clinical investigation of the efficacy of chemomechanical preparation with rotary nickel-titanium files for removal of endotoxin from primarily infected root canals. J Endod. 2010;36(11):1766-9. doi:10.1016/j.joen.2010.08.019 
12. Silva L, Nelson-Filho P, Leonardo MR, Rossi MA, Pansani CA. Effect of calcium hydroxide on bacterial endotoxin in vivo. J Endod. 2002;28(2):94-8. doi:10.1097/00004770-200202000-00011

13. Aranda-Garcia AR, Guerreiro-Tanomaru JM, Faria-Júnior NB, Chavez-Andrade GM, Leonardo RT, Tanomaru-Filho M, et al. Antibacterial effectiveness of several irrigating solutions and the Endox Plus system - an ex vivo study. Int Endod J. 2012;45(12):1091-6. doi:10.1111/j.1365-2591.2012.02069.x

14. Case PD, Bird PS, Kahler WA, George R, Walsh LJ. Treatment of root canal biofilms of Enterococcus faecalis with ozone gas and passive ultrasound activation. J Endod. 2012;38(4):523-6. doi:10.1016/j.joen.2011.12.020

15. Cassanelli C, Marchese A, CagnacciS, Debbia EA. Alteration of membrane permeability of bacteria and yeast by high frequency alternating current (HFAC). Open Microbiol J. 2008;2:32-7. doi:10.2174/1874285800802010032

16. Kuştarci A, Sümer Z, Altunbaş D, Koşum S. Bactericidal effect of KTP laser irradiation against Enterococcus faecalis compared with gaseous ozone: an ex vivo study. Oral Surg Oral Med Oral Pathol Oral Radiol Endod. 2009;107(5):e73-9. doi:10.1016/j.tripleo.2009.01.048

17. Lendini M, Alemanno E, Migliaretti G, Berutti E. The effect of high-frequency electrical pulses on organic tissue in root canals. Int Endod J. 2005;38(8):531-8. doi:10.1111/j.1365-2591.2005.00983.x

18. Signoretti FGC, Gomes BPFA, Montagner F, Barrichello Tosello $\mathrm{F}$, Jacinto RC. Influence of $2 \%$ chlorhexidine gel on calcium hydroxide ionic dissociation and its ability of reducing endotoxin. Oral Surg Oral Med Oral Pathol Oral Radiol Endod. 2011;111(5):653-8. doi:10.1016/j.tripleo.2010.11.016

19. Halbauer K, Prskalo K, Jankovic B, Tarle Z, Panduric V, Kalenic S. Efficacy of ozone on microorganisms in the tooth root canal. Coll Antropol. 2013;37(1):101-7. PMID: 23697257.

20. Oliveira LD, Carvalho CAT, Valera MC, Koga-Ito CY, Jorge AOC. Diffusion ability of endotoxin through dentinal tubules. Braz Oral Res. 2005;19(1):5-10. doi:10.1590/S1806-83242005000100002

21. Jacinto RC, Gomes BPFA, Shah HN, Ferraz CC, Zaia AA, Souza-Filho FJ. Quantification of endotoxins in necrotic root canals from symptomatic and asymptomatic teeth. J Med Microbiol. 2005;54:777-83. doi:10.1099/jmm.0.45976-0

22. Mohammadi Z. Endotoxin in endodontic infections: a review. J Calif Dent Assoc. 2011;39(3):152-5. PMID: 21563594.

23. Cardoso MG, Oliveira LD, Koga-Ito CY, Jorge AO. Effectiveness of ozonated water on Candida albicans, Enterococcus faecalis, and endotoxins in root canals. Oral Surg Oral Med Oral Pathol Oral Radiol Endod. 2008;105(2):e85-91. doi:10.1016/j.tripleo.2007.10.006

24. Farac RV, Pizzolitto AC, Tanomaru JM, Morgental RD, Lima RK, Bonetti-Filho I. Ex-vivo effect of intracanal medications based on ozone and calcium hydroxide in root canals contaminated with Enterococcus faecalis. Braz Dent J. 2013;24(2):103-6.doi:10.1590/0103-6440201301992

25. Tanomaru JM, Leonardo MR, Tanomaru Filho M, Bonetti Filho I, Silva LA. Effect of different irrigation solutions and calcium hydroxide on bacterial LPS. Int Endod J. 2003;36(11):733-9. doi:10.1046/j.1365-2591.2003.00717.x

26. Adl A, Motamedifar M, Shams MS, Mirzaie A. Clinical investigation of the effect of calcium hydroxide intracanal dressing on bacterial lipopolysaccharide reduction from infected root canals. Aust Endod J. 2015;41(1):12-6. doi:10.1111/aej.12054

27. Safavi KE, Nichols FC. Effect of calcium hydroxide on bacterial lipopolysaccharide. J Endod. 1993;19(2):76-8. doi:10.1016/S0099-2399(06)81199-4

28. Martinho FC, Gomes BPFA. Quantification of endotoxins and cultivable bacteria in root canal infection before and after chemomechanical preparation with $2.5 \%$ sodium hypochlorite. J Endod. 2008;34(3):268-72. doi:10.1016/j.joen.2007.11.015

29. Martinho FC, Gomes BP, Fernandes AM, Ferreira NS, Endo MS, Freitas LF, Camões IC. Clinical comparison of the effectiveness of single-file reciprocating systems and rotary systems for removal of endotoxins and cultivable bacteria from primarily infected root canals. J Endod. 2014;40(5):625-9. doi:10.1016/j.joen.2013.12.006

30. Vianna ME, Horz HP, Conrads G, Zaia AA, Souza-Filho FJ, Gomes BP. Effect of root canal procedures on endotoxins and endodontic pathogens. Oral Microbiol Immunol. 2007;22(6):411-8. doi:10.1111/j.1399-302X.2007.00379.x 